\title{
Social Movement Discourses and Conditions of Possibility in Bolivia and Mexico
}

\author{
Discursos y condiciones de posibilidad de movimientos sociales en Bolivia y \\ México
}

J. Carlos Domínguez / jdominguez@mora.edu.mx

Instituto Mora, México

\begin{abstract}
This work presents a comparative analysis of two Latin American social movements. The first case is the movement of opposition against the privatisation of water and sanitation services (ESS) in Cochabamba, Bolivia in 2000 and the second case is the movement of opposition against the project for a new international airport in Mexico City between 2001 and 2002. Both case studies illustrate how the study of collective discourses or collective action frames (CAFs) can be used to improve our understanding of social movements that emerge in the context of large infrastructure projects. The work argues that an important determinant in the development and life-span of a social movement is the extent to which the dialogical relation between collective discourses and processes of identity formation at the micro-sociological level is allowed or hampered by other contextual and organisational variables.
\end{abstract}

Key words: Comparative Politics in Latin America; social movements; collective action frames; contentious politics; infrastructure projects.

Resumen: Este trabajo presenta un análisis comparativo de dos movimientos sociales en Latinoamérica. El primero es el movimiento de oposición a la privatización de los servicios de agua potable y alcantarillado en Cochabamba, Bolivia, en el año 2000; y el segundo es el movimiento en contra del proyecto para un nuevo aeropuerto en la Ciudad de México (2001-2002). Ambos casos de estudio ilustran la manera como el estudio de los discursos colectivos y los marcos de acción colectiva pueden servir para mejorar nuestro conocimiento de movimientos sociales que surgen en el contexto de grandes proyectos de infraestructura. El trabajo argumenta que un factor determinante en el desarrollo y tiempo de vida de un movimiento social es la medida en que distintas variables contextuales y organizacionales facilitan o impiden la relación dialógica entre los discursos colectivos y otros procesos de formación de identidad a nivel microsociológico.

Palabras clave: Política comparativa en Latinoamérica, movimientos sociales, marcos de acción colectiva, política contenciosa, proyectos de infraestructura. 


\section{Introduction $^{1}$}

This work illustrates how framing strategies and discursive practices can be used to study and compare social movements across dissimilar socio-political contexts. For these purposes, two Latin American case studies are presented in detail. The first case study is the movement of opposition that was led in Cochabamba, Bolivia, by the Coordinator for the Defence of Water and Life [Coordinadora para la Defensa del Agua y de la Vida] in the year 2000 against the increase of fees and new water regulations that were deemed to be excessively biased towards the interests of private investors. This conflict has become known in the literature as the 'Cochabamba Water War'. The second case is the movement of opposition against a new international airport in Mexico City (NIAMC) which was led by the Popular Front for the Defence of Land [Frente Popular en Defensa de la Tierra, FPDT] between 2001 and 2002. The analysis is based on fieldwork data collection undertaken in Bolivia during the autumn and summer of 2005 and Mexico during the summer of 2002 and the winter of $2005 .^{2}$ Additional information has been gathered through the critical reading of other works on both case studies and recent interviews to policy makers. ${ }^{3}$

1 This research was possible tanks to the funding provided by Conacyt, Mexico, between 2002 and 2007 and the funding provided by the Department of International Development (QEH) from the University of Oxford in 2007-2008. The author also wants to thank Esteban Castro and Laurence Whitehead for their guidance throughout the research process.

2 More than 40 semi-structured interviews were conducted for every case study, encompassing a broad collection of social movement and public policy actors. The selection was done in two steps. First, interviewees were identified on the basis of their prominence in different media sources and on information provided by other actors knowledgeable of each conflict -e.g. from academia and NGOs. Second, additional interviewees were contacted during fieldwork visits. In the case of Mexico, the author visited the municipal head of Atenco when it was still taken by FPDT in 2002 and interviewed, in addition to leaders, lowrank and general sympathisers who were available. In the case of Bolivia, "water warriors" were identified with the help of the Democracy Centre in Cochabamba in 2005. Therefore, the interviews sited throughout the article constitute only a small fraction of the overall fieldwork. The interviews were complemented with an extensive revision of newspaper articles (see full list at the end of this article) and other documents, such as reports by government and international agencies (for additional information, contact the author).

3 In the case of the Water War, some examples are Assies (2003), Crespo (2000a; 2000b), Crespo and Spronk (2007); García et al. (2003), and Laserna (2000), among others. In the case of the NIAMC, some works include Davis and Rosán (2004) and Ortega (2005). 
Both Bolivia and Mexico show important differences including the size of the countries in terms of population and economy, the extent to which indigenous people have been mixed - i.e., mestizaje-, the strength and territoriality of the State, and the degree of political stability in the last fifty years. However, the comparison makes sense in the context of a storyline with similar ingredients: 1) a large infrastructure project or a public policy associated with the implementation or management of infrastructure projects that is promoted by a democratically elected government;2) social groups that mobilise to oppose and reject such initiative; 3) a social movement discourse that frames the project in the context of broader social and political demands; and finally, 4) the 'success' of contentious groups who accomplish the cancellation of the project and trigger social and political changes that surpass the project or public policy itself - e.g., by initiating longer cycles of protest or by undermining a regime's legitimacy-.

Almost a decade and a half has passed since both episodes took place and yet, a retrospective analysis sheds light on their historical significance and their impact on broader public policy practices. In the case of NIAMC, the cancellation of the project triggered a number of legal changes and became a reference for both policy makers trying to avoid similar conflicts around other infrastructure initiatives and social movement actors that experienced a sort of 'cognitive liberation'” after they realised it was possible, under certain circumstances, to contest successfully this kind of development and infrastructure megaprojects (Domínguez, 2011). In the case of Bolivia, the Water War initiated a longer cycle of protest that includes the so called Bolivian Gas War in 2003 and a protracted political crisis that culminated with the election of President Evo Morales in 2005 and a Constitutional Assembly in 2009. Interestingly enough, the administration of Morales also faced social protests against plans to build a new road through a natural reserve in 2011 and 2012, becoming an example of how the implementation of infrastructure and development projects can create political tensions even if they are promoted by a democratically elected government.

Furthermore, the Bolivian Water War and the airport controversy in Mexico City are not isolated case studies. Other Latin American countries have also witnessed the emergence of similar social movements and the cancellation or indefinite postponement of mega-infrastructure projects

4 According to social movement theorists, this concept refers to the '... ability to break out of pessimistic and quiescent patterns of thought and begin to do something about [one's own] situation...' See Kurzman (1996:154), based on the original concept of McAdam (1982). 
and/or policy reforms in the public services sectors such as water, energy, and telecommunications. Therefore, taken together, the two cases under study signal a more generalised trend that affects Latin America. This trend suggests that the process of designing, promoting, and implementing infrastructure projects requires a thorough rethinking in the context of economic, social, and political transformations that the region has experienced in the past two decades. From an academic point of view, this supposes a more serious study of how and why social movements such as the Coordinadora in Bolivia or the Frente Popular in Mexico emerge, legitimise themselves, participate in the discursive field, gather momentum, attract powerful allies, and trigger political impacts that surpass the infrastructure project in question.

This article argues that the framing strategies of both social movements were determinant to problematise public policies, to build collective identities, and to create bargaining resources that contributed to oppose both policy initiatives effectively. However, it also argues that there is a dialogical relation between discourses publicised by social movements in the public sphere and the construction of identities at the micro-sociological level. In this respect, the most significant difference between Coordinadora in Bolivia and Frente Popular in Mexico was the extent to which contextual and/or organisational conditions hampered or facilitated this dialogical relation, impacting on the movement's capacity to maintain and increase their legitimacy and internal cohesion.

The rest of the work is divided as follows. Section two presents a brief theoretical discussion on the study of collective action frames and framing strategies. Sections three and four use these theoretical concepts to analyse both case studies. Section Five complements the discussion with a short comparative exercise.

\section{Theoretical Background}

\section{Discourses, Collective Action Frames, and Conditions of Possibility}

The analysis of framing processes and more concretely, the study of the construction and role of collective action frames (CAFs) has become one of the most popular theoretical approaches for studying social movements in the last twenty years. According to this view, collective action is partly determined by the subscription to a certain explicit discourse that provides a frame to understand the world out there, organises experience, and guides 
action (Snow and Benford, 1992: 133-137; Snow et al., 1986: 466; Snow and Benford, 2000: 613-617). Thus, collective action frames are conceived as 'conscious strategic efforts by groups of people to fashion shared understandings of the world and of themselves that legitimate and motivate collective action' (Snow and Benford, cited in MacAdam et al. 1996: 6). This theoretical approach is not strange to the study of Latin American social movements. Some authors who have applied this kind of approach include Bayard de Volo (2004), Bruhn (1999), Domínguez (2007), Hammond (2004) and Noonan (1995).

A CAF is a discourse with the symbolic power to turn grievances into worthwhile reasons to mobilise (Snow and Benford, 1992; and Tarrow, 1994) and to turn things considered natural into social or political problems. In other words, CAFs explain how issues become morally imperative in spite of associated risks and low probabilities of success (Snow et al., 1986: 466). A clear example is the problematisation of privatisation policies in the water and sanitation sector. From a technical and economic point of view, in the last two decades privatisation has been considered 'natural' and unavoidable to use public-private-partnerships and other forms of private participation as means to increase the coverage and to improve the quality of the water and sanitation services (WSS). For this reason, any opposition needs to reveal the social and political problems that are associated with such a scheme and to introduce new conflict dimensions. In a few words, it is necessary to overcome the 'mobilisation of bias' (Schattschneider 1960), to 'denaturalise' policies, and to strip them from their aura of inevitability.

The case of an airport project constitutes a similar example. From a governmental and developmental point of view, an airport is framed as a sign of modernisation and economic development. It is usually considered to be essential to support trade, economic growth, and human mobility in general. From a different angle, however, an airport may also represent serious disruptions to the social fabric of the communities that are displaced and/or irreversible environmental impacts. Highlighting these aspects is part of the problematisation necessary to articulate the opposition against this kind of projects.

Once a movement has won legitimacy and justified its existence in the public arena, such problematisation should also work to convince potential supporters and allies that it is worth mobilising and participating in different movement activities, even if there is a good chance of being repressed. In this way, a $\mathrm{CAF}$ is a discursive instrument that requires symbolic elaborations with the power to increase recruitment possibilities, activate organisational 
resources, and access powerful allies. It borrows from existing collective identities, political cultures, cultural traditions, ideologies, and societal mentalities, all of which contain the symbolic power to project new identities and justifications to act collectively. A message and how it is proposed to target groups determine if a mobilisation occurs or not (Gamson, 1992: 58; Snow and Benford, 1992: 133-137; Tarrow, 1992: 174, 180).

A CAF cannot assume that participants in a social mobilisation are homogeneous. Even if they share a grievance, they have various backgrounds, interests, and opinions with regard to other spheres of life. In this context, a CAF has an effect upon who and how long they mobilise for. It has a strategic character and cannot be a simple projection of culture and collective identity into the political field. The main challenge for leaders is to frame claims so that a movement gathers sufficient critical mass. It needs to be familiar enough to be understood by the members of the movement, but flexible enough to adapt to changing circumstances and attract potential allies. To achieve both objectives simultaneously, the available symbols and meanings should be worked and readapted (Snow and Benford, 1992: 136; Tarrow, 1994: 109).

There are three main criticisms worth taking into account. Firstly, scholars focusing on discourses and framing strategies often pay little attention to the agency and emotions involved in the interpretation of collective action frames by individuals. Secondly, identity cannot be conceived exclusively as a pre-condition for collective action. As Melucci (1989) and Gamson (1991: 42) argue, identities and values are actually embedded within collective action. They are much more than mere rhetorical devices. They are embodied in concrete practices and they are often re-produced through ritualistic activities that reinforce sentiments of belonging, as in the case of many social protests (Della Porta and Diani, 1999: 98). Third and finally, movement discourses are not unequivocal and deterministic. Their influence on the development and life-span of a social movement depends on an intricate interplay with other variables, including organisational resources and political opportunities.

This work rests on the assumption that the two first criticisms can be addressed if social movements are explained in the context of a dialogical relation between discourses publicised in the public sphere on the one hand, and processes of identification at the micro-sociological level on the other (Steinberg, 1999). In this view, a social movement is likely to achieve greater cohesion and maximise its life-span and impact as long as collective frames stay aligned with changing identities and demands across different 
constituencies. Leaders and spokespeople do play a central role in articulating and publicising claims, demands, and identities, but they constantly face the limits imposed by the 'people's fundamental sentiments' (Berbrier, 1998: 440 ) and by less visible processes of identification that are multivocal.

The third criticism can be addressed if the development of a social movement is tied to the contextual and organisational conditions that allow or hamper such dialogical relation. Presumably, a social movement that is characterised by a less hierarchical organisation and/or that faces a political environment which is more favourable for mobilisation has better chances to align collective frames with the aspirations of potential supporters. Thus, in this view, framing processes and discursive strategies are still central for explaining the emergence, development, and final outcome of a social movement but their centrality is understood within a kaleidoscopelike explanation where resources, opportunities, and hidden processes of identification are still strong co-determinants.

\section{'Water as a Condition for Life': Powerful Discourses and Coordinadora in Cochabamba}

\section{Coordinadora: 'An Association of Associations'}

The privatisation of wss in the city of Cochabamba, Bolivia was promoted by the government of Hugo Banzer and backed by international financial institutions in year 1999. This scheme was implemented through a concession awarded to Aguas del Tunari (AdT) - a private consortium backed by Bechtel International. The respective contract was tied to the implementation of the Misicuni Multipurpose Project (MMP), which included the construction of a dam to increase the supply of drinkable water in urban areas of Cochabamba and water for irrigation in surrounding rural districts. For many decades MMP had been conceived as one of the main projects to foster development in the whole department of Cochabamba. However, the main obstacles to the implementation of these policies were: 1) the need to increase water fees to extend the water network and to make MMP feasible; and, 2) the need to change existing regulations to allow the privatisation of wss in the country. In both cases, these measures led to social and political tensions that resulted in street protests by different urban and rural actors claiming that the government colluded with private actors to exploit water resources to the disadvantage of the most marginalised and disrespecting uses and customs. 
In this context, Coordinadora was created in November 1999 to coordinate the efforts of urban and rural organisations that opposed water reforms. Little by little, different groups, including neighbourhood associations, academics, farmers, middle-classes, students, and cocaleros [coca growers], joined the social movement. Even different strands of the media joined in condemning the government responses, which included a state of siege, broken promises to reverse the water concession, and the detention of movement spokespeople a few months after mobilisations had begun.

Coordinadora represented a collection of different urban and rural groups. In words by García Linera et al. (2004: 634), it was an 'association of associations' that was extremely diverse, and thereby, CAF was a key element to achieve cohesion and sense of direction. Beyond the organisational details, a significant challenge was the construction of an identity that was familiar and sufficiently flexible to be shared by dissimilar constituencies. It required a discourse with the symbolic power to turn grievances into worthwhile reasons to mobilise. This discourse was based on a very simple and yet powerful argument: the idea that water is a condition for the reproduction of life, that the right to have water is inalienable, and thereby, that its management concerns everybody (Interviews with Olivera, 13-08-05 and López, 13-08-05). This became the foundation for a shared identity since the marketisation of water and the privatisation of wss not only affected those who managed water sources in rural areas, ${ }^{5}$ but those paying higher fees in the city (Interviews with Crespo 11-08-05 and Olivera 12-08-05). Thus, the elementary meaning of water as a condition for life became the overarching theme that eclipsed potential conflicts between urban and rural groups and provided an identity-umbrella for both of them.

The discourses and identities deployed by Coordinadora were not static but experienced different transformations throughout the Water War. In this respect, it is possible to recognise at least three of the processes proposed by Snow et al. (1986): the linkage between two previously unconnected frames; its extension to cover a broader group of supporters; and finally, the partial displacement of one discursive universe by another.

\section{Constructing Urban-Rural Alliances}

The umbrella-identity that was shared by urban and rural groups supporting Coordinadora was only possible because of the linkage between two discourses

5 In the absence of big projects such as MMP, the extraction of underground water in rural areas constitutes the main source of water supply for the city of Cochabamba. 
which had been unconnected up to that moment or had been connected circumstantially and only in a tangential manner. One of these is based on the uses and customs kept by regantes [farmers that control traditional water systems] in the rural areas of Cochabamba. The other was based on the idea of defending households' meagre economy and on the demand to implement social control over policies promoted by the state; this is say, to build a more participative democracy. In this respect, three cultural themes were present in both collective action frames, working as a sort of 'hinge' between the two.

The first was the importance of 'solidarity' and 'reciprocity' as fundamental values to sustain the social fabric, both in clear opposition to the individualism and mercantilism characteristic of the technocratic discourse employed by institutional actors. The second discursive ingredient that functioned as a 'hinge' between the urban and rural worlds was the idea of 'the people' or 'plebeian crowd' ${ }^{\text {' }}$ as a social body or collection of social entities whose mobilisation constituted - somewhat tautologically- a source of legitimacy for the social movement. That is, the idea that Coordinadora did not exist beyond the demands and preoccupations of the people and that it did not exist beyond the people's self-organising capacity and ability to surpass traditional ways of mobilisation helped legitimizing the movement.

The third and final linkage was the simple idea that water is a condition for life and therefore has a natural, social, and historical meaning that transcends any economic valuation. As explained with more detail below, in the case of regantes, this is an idea based on prevailing uses and customs with a long historical and cultural background. In the case of urban groups, the cultural and historical value attached to water is more ambiguous and less visible. Only in the more economically and socially marginalised areas -like the south of the city- is it possible to find that such non-economic value is based on communal efforts undertaken during the last two decades to implement traditional water systems to offset the limited access to formal networks. Still, the collective action frame that was publicised by regantes sparked a similar discourse in the city; a discourse that legitimised and justified the support of other urban sectors - in addition to those with a high degree of economic and social marginalisation-.

6 The concept of 'forma multitud' or 'multitud plebeya', also translated as the 'multitudeform' [of collective action] was originally coined by Bolivian intellectual René Zavaleta (1983) and has been recently adopted — and adapted - by other intellectuals and activists such as Alvaro García Linera (see García Linera, cited in Olivera and Lewis, 2004: 71-79 and García Linera et al., 2000: 151). 


\section{Extending the Pool of Supporters}

The CAF that made the urban-rural alliance possible was also based on discursive elements that were sufficiently flexible to attract other powerful allies beyond regantes or neighbourhood associations from the south of the city. The main element has a historical-ideological character, which according to the personal views of social leaders and academics who sympathise with the social movement, makes reference to a long fight against 'unjust' elites and 'repressive' governments. From this point of view, the mobilisations in April 2000 signalled the revival of ways and levels of social mobilisation that had not existed since 1986, after Marcha por la Vida (García Linera et al., 2000: 125).

In this context, the resistance movement headed by Coordinadora could be framed in a longer and broader fight; one that transcended the privatisation of water and sanitation services. In other words, it became yet another chapter of the Long Bolivian History (Interviews with Quintana 0805 and Mamani 09-05), which includes events such as the siege that was led by Tupac Katari in 1781, the Revolution of 1952, and many other episodes when the people - particularly indigenous people - exerted their right '...to become guides of the country's destiny...' (Interview with Mamani 02-1003). The last chapter of this Long History — the resistance against neoliberal policies - began fifteen years before the Water War, when the government of Paz Estenssoro launched the implementation of market reforms in 1985. Thus, the circumstances that catalysed the Water War such as the secret agreements between official authorities and AdT made the extension of the collective action frame easier. A few months after Coordinadora began its mobilisation efforts it was evident that the pronoun 'we' not only referred to those who opposed the privatisation policies in the water sector, but to all those who opposed neoliberal policies in general. This way, it became possible to enlarge the universe of potential supporters and to legitimise the participation of important allies. A clear example was the coca growers from the tropical areas of Cochabamba, headed by Evo Morales.

7 Marcha por la Vida [March for Life] was a protest in which around 30,000 people participated. It took place in August 1986 after the government announced the closure of mining centres given the collapse of tin prices. 
Frame Displacement and the Conclusion of the Water War

The third and final framing process - closely related to the CAFs own flexibility - was the displacement of one discursive universe by another. Claims publicised by Coordinadora changed gradually as the conflict evolved and stances became more polarised. They shifted from demanding the revision of the contract with AdT and the content of new water regulations to their respective cancellation and annulment. Those changes were a response to many political and operational mistakes that the government committed while implementing the new water policy.

The changing demands and more specifically, the subtle modifications in rhetoric such as using the verb 'cancel' instead of 'revise' or 'annul' instead of 'modify', implied substantive changes in two aspects of the social movement (Domínguez, 2007). It altered its action orientation and its source of legitimacy in the public space. Consequently, the constructed collective identity was also transformed. These two changes signalled the displacement of a discursive universe wherein the validity, functionality, and appropriateness of institutional boundaries as legitimate boundaries to engage in politics and design public policies were questioned; by another discursive universe wherein such boundaries should be totally annulled and substituted.

Furthermore, the leaders themselves did not realise that the pronoun 'we' had changed again. Not only did it now refer to those opposing unjust public policies, but to those that may and should take control of the policy process (Dominguez, 2007). Thus, on 10 April 2000, after many confrontations between the police and military on the one hand, and civil society on the other, the contract with AdT was finally cancelled, the water company reverted back to municipal ownership, and a model of control social [social accountability] was later implemented. A new law that affected uses and customs in rural areas was amended one month later after heated negotiations between regantes and government representatives.

Over the years, the Water War became a milestone in the history of social movements and public policies of Bolivia. For the first time since neoliberal reforms were initially implemented, Bolivia experienced large scale mobilisations that rejected, in an articulated manner, the introduction of market policies in the water and sanitation sector. The Water War was also the first major conflict in a long queue of protests, marches and mobilisations that culminated in the forced resignation of President Gonzalo Sanchez de Lozada halfway through his second mandate (2001-2003), as well as the 
toppling of an interim president in 2005, the election of the first indigenous president, and the call for a Constituent Assembly at the end of the same year.

Although Coordinadora del Agua y de la Vida became gradually less active after the Water War ended, the same organisational model was replicated at a larger geographical scale when Coordinadora del Gas formed to oppose a project to export liquefied natural gas (also referred to as PacificLNG) to California (Olivera and Lewis, 2004: 158, 177; Perreault, 2006). Many spokespeople and leaders who were protagonists during the conflict in Cochabamba also became central actors in subsequent political struggles. The most emblematic is Evo Morales, whose visibility as a leader of cocaleros increased precisely during the Water War (Van Cott, 2003: 755) and whose political capital helped him to become president in 2005. As a result, the balance of power shifted in favour of left-wing and non-traditional political parties such as Movimiento al Socialismo (MAS).

The next section presents the Mexican case study and confirms the usefulness of these analytical categories to identify patterns and points of comparison across different instances of social mobilisation. It identifies similarities between the social movements led by Coordinadora in Cochabamba and Frente Popular in Mexico City, even though their outcomes and long-term consequences differ sharply.

\section{The Case of Frente Popular in Mexico City}

\section{'Deaf Ears' and Unjust Expropriations}

The project for a new airport in Mexico City was promoted by the administration of President Vicente Fox in the years of 2001 and 2002. This project had been on and off the governmental agenda for more than three decades and its implementation had been discarded and/or postponed by the five presidents before Vicente Fox. According to the official version, the site for the project was chosen on the basis of its technical-aeronautical advantages, cost-benefit analysis, minimisation of environmental impacts, and opportunities for socio-economic development. Moreover, the new airport was conceived as one of the most important projects of the new democratically elected government after seventy years of hegemony by the Institutional Revolutionary Party (Partido Revolucionario Institucional, PRI). The main obstacle, however, was the necessity to expropriate 5,391 hectares of ejidos and displace 4,375 landowners who live in the municipalities of Atenco and Texcoco, in the south-eastern outskirts of Mexico City. 
The groups rejecting the project created the Popular Front for the Defence of Land [Frente Popular en Defensa de la Tierra]. ${ }^{8}$ The call to fight for the land swept through other communities that were affected by the expropriation decrees (EDOMEX, 2003). Even beyond Texcoco and Atenco, the general population felt uneasy with the expropriation decrees. A variety of non-governmental organisations (NGOs), intellectuals, writers, journalists, former members of the 1968 student movement, and other public figures condemned the project. In just a few months the protesters included radical students, striking teachers, and sympathisers of the Zapatista Movement in Chiapas. Overall, it was perceived as an outrage from the government. In some cases, the protests became an opportunity to express discontent about other issues such as neoliberal economic policies, the North American Free Trade Agreement (NAFTA), and the expected reforms in the tax system and energy sectors. Reciprocally, members of Frente Popular began supporting other contentious groups that all had one thing in common: 'the fight against an outrageous and incomprehensive government' (Interview with Espinoza 08-03).

The communities affected by the expropriation decrees faced the most adverse scenario: the Fox administration was promoting one of the most important projects of the sexenio (6-year mandate) and as the 'government of the democratic transition' it seemed to have all the necessary political capital to do so. Moreover, the decision to build a new airport had been delayed for more than three decades, and to a certain extent, it had been turned into a kind of mystified prophecy whose time had come: its implementation seemed inevitable. To overcome these challenges people in Atenco and surrounding communities needed to activate whatever organisational resources they had in order to appeal to powerful allies and mobilise national and international public opinion. In this context, it was crucial for Frente Popular to craft a suitable CAF to oppose the project of a new airport. As in the case of Coordinadora in Cochabamba, it was necessary to create bargaining resources and to overcome the mobilisation of bias.

The CAF in Atenco was socially and historically grounded on the importance of 'solidarity with our people' and 'solidarity around the land' (fieldwork interviews). This idea was not new and did not appear spontaneously; it already existed when the Federal Government announced the expropriation decrees. Thus, the expropriation was not an isolated event but constituted the 'straw that broke the camel's back'. In the words of the

8 Also referred to as Frente de Pueblos en Defensa de la Tierra. 
main spokesman of Frente Popular, '...people here [in Atenco] were used to face the government's bureaucracy... and the government's arbitrary and clientelistic decisions [regarding the provision of services and public goods, including justice and basic civil rights]...Therefore, protest was already latent inside each one of us...' (Interview with Del Valle, 08-03).

The social value of 'solidarity with our people' is a cultural construction that is valid independently from the expropriation decrees. It has been socially embedded as a result of adversities that these people have historically faced living in the outskirts of Mexico City; and in the context of the disenchantment with the state, ${ }^{9}$ its apparent indifference towards Atenquenses [people from Atenco], and their perception that it has always been better to solve their social and economic problems by themselves (Interview with Del Valle 08-03). However, the expropriation decrees added a new dimension and made apparent the fact that Atenquenses were in a structurally contradictory position against the state.

In this respect, the references to historical adversities constituted the foundation of important mobilising structures that were developed long before the announcement of NIAMC. In other words, this was not the first time that Atenquenses united to solve a problem. They had organised before to construct water wells, acquire farming equipment, expel illegal settlers, as well as fight 'the injustices of the state'. Informal social networks, which are grounded on the everyday life experiences of Atenquenses, were crucial for the Frente Popular. These include celebrations around the land, such as festivities to venerate and to express gratitude to Saint Salvador and other saints for the opportunity to work the land, no matter how good or bad the harvest is. Other social events, such as funerals, weddings, baptisms, pagan celebrations during Carnival, and Easter festivities also provide the organisational learning experience that is useful to face adverse circumstances.

\section{Extending the Pool of Adherents in Atenco}

But local networks were not enough to guarantee the success of the social movement headed by Frente Popular. Right from the beginning, the Atenquenses who joined the movement knew that it was necessary to obtain support and to activate informal social networks beyond their own villages. Citing a member of Frente Popular, '...we knew that there was no way to do

9 The people in Atenco used indifferently the terms 'state' and 'government'. Both terms usually encompass the different government levels — federal, state and municipal—. 
this on our own...we began to mobilise, to visit other villages, and to diffuse our movement nationally and internationally...' (Interview with Espinoza, 08-03).

Therefore, the collective action frame of Frente Popular did not make exclusive reference to the grievances of the people in Atenco. The constructed categories were broad enough to be shared by other actors. It was possible to identify the unfavourable terms of the expropriation decrees as the source of grievance, the 'state' and the 'bourgeoisie' as the enemy, and 'all those who fight against the government's injustices' as potential supporters of Frente Popular (fieldwork interviews; EDOMEX 2003). Even if it was only through public stances, the people in Atenco and surrounding municipalities were supported by diverse actors because the constructed frame was appealing and/or convenient for them. These included international NGOs, legal and technical advisors that volunteered independently, the left-wing Government of Mexico City, and the Zapatista movement. In other words, their particular demands and statuses echoed in and identified with the causes of Frente Popular.

In some cases, such resonance was straightforward. For example, the discursive and visual allusions to the revolutionary hero Emiliano Zapata and the use of machetes as visual symbols constituted a kind of frame amplification (Snow et al., 1986: 470): a successful attempt to identify, increase the visibility, and idealise the importance of land and the historical fight associated to defending this resource. This strategy appealed to other peasant movements around the country. The Zapatista Army of National Liberation [Ejército Zapatista de Liberación Nacional, EZLN], groups from Tepoztlán, Morelos, and in the last stages of the conflict, members of the Popular Revolutionary Army [Ejército Popular Revolucionario, EPR] constitute only a few examples, perhaps the most visible ones.

In the specific case of $Z$ apatistas, there was a two-way relation between their discourse and that of Frente Popular. On the one hand, as one of the first, best known, and popular indigenous anti-globalisation movements in the world, the Zapatista Movement has diffused and consolidated a powerful master frame, a kind of collective action frame that fulfils the same functions - i.e. condenses the world out there-, but on a larger scale and in a way that constrains the discursive choices of other social movements coming afterwards (Snow and Benford, 1992: 137-138). This phenomenon is not exclusive to Mexico: the Zapatistas are perceived all around the world as an obliged reference for human rights, indigenous, environmental, and antiglobalisation movements alike. 
Discursive references and strong movement stances such as $;$ No hay pais sin maiz! ['...there is no country without corn'] and iLa tierra no se vende, se ama, se defiende! ['...the land should not be sold; it should be loved and defended'] are often found in the first discourses and communiqués of the EZLN. They were reproduced textually — or almost textually - by Frente Popular during the conflict in Atenco.

The other way round, Zapatistas were somehow obliged to respond to this gesture. After all, the Zapatistas' extensive network of alliances with other social movement organisations (SMOSs) and international NGOs has been forged on the basis of this kind of sympathetic and moral exchanges. Moreover, this is one of the few reasons why the Zapatista movement has stayed alive despite the inevitable exhaustion, divisions, and demoralisation of almost a decade of fighting without winning more than small material victories (Nash, 2001: 231). Following Le Bot (1997: 20, cited in Bruhn, 1999: 48): '...it is like an agreement: [the international allies] get from Zapatismo what they need, the reminder [to struggle], that trampoline to take off again, and the [Zapatista/indigenous] communities get that backing, [the] help that guarantees their survival...'

The categorisation of the airport as a 'bourgeois' and 'neoliberal' project served as a kind of frame bridging between the causes of Frente Popular and the causes of other 'victims' of the neoliberal state such as striking teachers, members of Consejo General de Huelga, CGH [General Strike Council], and other SMOs, whose associational roots are found in the resistance against population displacement and land expropriations. The most illustrative example is Frente Popular Francisco Villa (FPFV), a SMO that was created in 1989 when thousands of families were expelled from a natural reserve located in the south of Mexico City.

At the same time, the message of Frente Popular became appealing to a more diffuse, but not less important actor: public opinion. In other circumstances, it would have been difficult for the 'ordinary citizen' to decide if the expropriation decrees were just or unjust. The issue is ambiguous because an expropriation decree is issued on the basis of public interest and such a concept is elusive and contested. However, this was not the case in Atenco and Texcoco because the land was compensated at an obviously unjust price for two reasons: a) the land was valuated at $7.5 \mathrm{MXN}$ per square meter - 25 MXN in the case of irrigated land-; and, $b$ ) although the land was hardly productive and had very few alternative uses at the time, it would be used to develop the most important airport in Mexico. 
Frame Transformation and the Decline of Frente Popular

Nearly one year after the public announcement, the resettlement and expropriation negotiations failed and the movement of opposition radicalised sharply. Members of Frente Popular organised a 'local coup' in Atenco and declared it an 'autonomous municipality' (Reforma 22-09-02; Salinas and Alvarado 11-07-02). The conflict reached its peak on 11 July 2002. A violent confrontation with local police took place when representatives of Frente Popular tried to approach the Governor of the State of Mexico during a public ceremony. Thirteen peasants including two main leaders were arrested, while nineteen police officers were taken as hostages. The tension grew when Frente Popular threatened to burn the hostages alive, and was not resolved until State of Mexico authorities agreed to exchange prisoners.

On 1 August 2002, President Fox announced the cancellation of the project. The central argument was that the costs of any additional negotiation had far exceeded the benefits of Texcoco as a possible policy alternative. The cancellation came so abruptly that even high standing civil servants within the transport sector were taken by surprise. In Atenco, when the expropriation decrees were cancelled, the movement's action orientation changed and the CAF took anotherview based on three new demands: $a$ ) the family of a peasant who died during confrontations with policemen should be compensated; $b$ ) all arresting orders against members of Frente Popular should be cancelled; and, c) Atenco should be declared an 'autonomous municipality'.

The first claim seemed to be just and could constitute the basis to justify further support from external allies, such as human rights organisations. However, the idea of revoking the arrest warrants was controversial because the distinction between collective violence and crime is difficult to delineate (Tilly, 2003: 19). Even when certain acts are legally defined as forbidden, the frontier between illegality and illegitimacy is blurred if an act that is prescribed by law is clearly unjust -e.g. the expropriations decrees in Atenco and Texcoco-. In this respect, Frente Popular became increasingly radical by the end of the conflict. Leaders and supporters blocked roads, burnt vehicles, took public servants as hostages, and threatened to kill them. A change in the tactical repertoire and the mere ambiguity of this new grievance-revoking arresting orders- might have alienated some allies of the Frente Popular. Actors that had hitherto sympathised with and supported the movement, such as the left-wing government of Mexico City, academics, as well as technical and legal advisors preferred to cut themselves off from the events in Atenco and Texcoco. 
The third claim — declaring 'autonomous municipalities' - is contested in Mexico because it has deep implications for the social and political cohesion of the country. Even in the case of Chiapas, where the communities demanding to become autonomous are clearly different in terms of customs, traditions, and language, the Mexican government has hesitated to grant such autonomy. One reason is that the definition of who actually is indigenous is not straightforward, especially since the boundaries of 'indianness' continue to widen even in remote rural areas of the country. At the same time, government representatives have expressed concern over the incompatibility between customary laws on the one hand, and basic individual civic and political rights on the other.

Thus, overall, the demand for municipal autonomy found little backing amongst the movement's allies. Even within the population of Atenco, it is not clear if there was widespread support for such political aspiration. Frente Popular and Atenquenses in general, showed deep divisions after the airport project was stopped in 2002. Many communities that had eventually reached an agreement with the Federal Government expressed their disenchantment when the airport was cancelled and some disputes between members and non-members of Frente Popular have been registered thereafter (EDOMEX 2003; Reforma 04-08-02; and fieldwork interviews). The most dramatic of these quarrels took place when movement leaders tried to obstruct municipal elections in 2003 and were met with sticks and stones by inhabitants of Santa Isabel Ixtapan (Reforma 10-03-03).

\section{Comparative Politics: Conditions of Possibility in Bolivia and Mexico}

\section{Conditions of Possibility in the 'Water War'}

The case of the Water War is illustrative of a dialogic relation between both universes: the universe where identity is embedded in action and the universe where it works as a precondition for it. Far from the romantic idea the rank and file played a protagonist role in articulating demands, identities, and strategies, they actually set the limits for the articulation of identities and discourses by the leaders - or spokespersons - of the movement. On the one hand, it is possible to talk about a multiplicity of stories that converged and derived in shared identities in houses, streets, trenches, and other spaces that are usually less visible. These are processes that were not registered - or at least not immediately - in the media and that did not play a paramount role to publicise the movement among other actors. But simultaneously, 
there was a protagonist role that leaders and spokesmen played in articulating demands and identities that were projected in the public sphere and that had a specific weight in the relations between Coordinadora and the government and public opinion.

The conditions that allowed this dialogical relation derived from a historical, economic, and socio-political context that already existed in 2000, independently from the social movement led by Coordinadora. This scenario facilitated the 'frame's salience to the targets of mobilisation' (Snow and Benford, 2000: 621). These conditions of possibility, defined as the contextual and organisational conditions that allow the resonance between constructed discourses and collective identities during the visible and the non-visible phases of a social movement were mainly three. Two of these conditions were external to the social movement or socio-political contextual and one of them was internal or organisational.

The discredit of neoliberal policies accumulated during the last fifteen years, together with the difficult situation that Bolivia experienced in 2000 constituted the first condition of possibility for the discourse of resistance endorsed by Coordinadora. This scenario contrasted, for example, with the scenario that prevailed during the March for Life in 1986. Back in those years, the traumatic experience of hyperinflation, the recurrent economic and political crises during the 1970s and 1980s created a context that was much less favourable for a social movement to construct a CAF that contested the public policy discourse used to legitimise the implementation of neoliberal policies. In other words, by the mid-1980s it was possible to grant the benefit of doubt to the proposal of a new economic model, based on a smaller state and the market as the main instrument to assign economic resources. But in 2000, it was clear that many promises associated with this new model had not been fulfilled.

The low levels of legitimacy enjoyed by a loose governing coalition led by former military dictator Hugo Banzer constituted the second condition of possibility. In the first years after the political transition of 1982 it was easier to endorse a democratic discourse that was based on a narrow conception of democracy as electoral democracy. Back in those days, Bolivia was considered a model to follow in terms of modernisation and soundness of the electoral and political party system. Nevertheless, fifteen years later, in 2000, Bolivia was experiencing a crisis of political representation and it was much more difficult to support the same discourse when it was already clear that traditional political parties had failed in their attempt to fill the gap of representation and participation left behind by the union movement. It is in 
the context of this gap that Coordinadora's CAF about the need for a more participatory scheme found resonance and became possible.

The third and final condition of possibility is related to the Coordinadora's organisational structure. Compared to traditional movements such as the workers' movement led by the Bolivia's Workers Union (Confederación de Obreros de Bolivia: COB) or the peasants' movement led by the Confederation of Peasant Workers from Bolivia (Confederación Sindical Única de Trabajadores Campesinos de Bolivia: CSUTCB), both of which have vertical and hierarchical structures, Coordinadora was a loose, flexible, and non-hierarchical network. At the same time, Coordinadora did not create a boundary between members and non-members. On the contrary, there was no strict membership of this SMO except for the informal partisanship that was shown through action itself. In contrast with Сов or the CSUTCB, the decision to join was not contingent on fixed categories such as 'being a peasant' or 'being a worker' but was completely voluntary. This opened the door for a flexible constituency that grew or shrank depending on the particular situation. Everyone contributed to different social movement activities and provided their input on tactics and strategies and on the articulation of claims and demands. The 'pluriformity' of this amorphous SMO helped leaders and spokesmen to create a common frame of reference based on simple and powerful ideas such as 'participatory democracy' or 'water as a condition for life'.

Together, these three conditions of possibility moulded a specific conflict scenario that helped different individuals, from all walks of life, to identify through their personal stories and their respective actions of resistance. These conditions also allowed the CAF to make sense in the public sphere and to work as an instrument to publicise the pronouns 'we', which subsumed and gave sense of direction to the heterogeneity and multiplicity of individual experiences. Compared to the mobilisations registered in the mid 1980s, these three elements facilitated the resonance between the different levels of the social movement.

\section{Conditions of Possibility in Atenco}

The case of Atenco shows a slightly different story. Although Frente Popular crafted a CAF that helped to publicise existing grievances, to construct strong collective identities, and to appeal to powerful movement allies, this SMO did not face the same conditions of possibility that Coordinadora 
did in Cochabamba. In this respect, it is worth mentioning at least four obstacles that hampered the resonance between constructed discourses and collective identities during the visible and the non-visible phases of the social movement in Atenco: the extent that social movement alliances were sustainable throughout the various stages of conflict, the political context, the organisational traits of Frente Popular, and the movement's framing strategies towards the end of the conflict.

Firstly, a closer look to the movement headed by Frente Popular in Atenco reveals that there were two kinds of supporters in the affected communities: those who wanted to stop the project at any cost and those who wanted to bargain for a better deal with the government. Both groups backed the creation of Frente Popular and agreed on strategies that were pursued at the beginning of the conflict in Atenco and Texcoco. They worked together to attract powerful allies, gain critical mass, and create bargaining resources. It was necessary to gain visibility, to appeal to public opinion, to problematise the airport project, and to expand the scope of conflict. However, their ultimate goals and political orientation differed sharply and some supporters of Frente Popular eventually became disaffected.

On the one hand, choosing Texcoco as the ideal site to build the new airport put the affected communities on the map. This situation represented 'the opening of political space' (Gamson and Meyer, 1996: 277): those semi-urban people who had been living in an institutional limbo became unexpectedly important from a developmental point of view; even if it was just because the land where they were living was necessary to build the NIAMC. Although the airport project represented a grievance, it also presented an important opportunity to improve the conditions in Atenco and Texcoco. In other words, it represented a chance for communities that had remained invisible to public policies for more than three decades to place their demands, raise their voices, and attract the attention of authorities. This was the case of the moderate factions within Frente Popular.

On the other hand, although the conflict in Atenco did not open any substantial space for the emergence of alternative ways of political and social representation, as it occurred with Coordinadora in Cochabamba, the airport project did represent a new opportunity for social movement organisations that had traditionally opposed PRI and that became opposition 'orphans' and lost their political flag after the historical elections in 2000 (Interview with Kuri-Pérez, 12-05). The magnitude of the airport project and the initial leanings of public opinion exerted a kind of gravitational effect: everyone 
wanted to be in the picture, because it was an opportunity to show that the right-wing Partido Acción Nacional, PAN, [National Action Party] had to pay its dues if it was to claim the title of gobierno de la transición [government of transition].

However, when Frente Popular changed its demands - e.g. calling for municipal autonomy-, transformed its collective discourse, and resorted to more radical repertoires of contention, it induced a realignment of its own movement allies. As already mentioned above, institutional actors and technical and legal advisers distanced themselves from events in Atenco; public opinion became less favourable for the movement; and many affected communities withdrew their support to Frente Popular. At the same time, new actors came into play. Frente Popular attracted groups that are more radical compared with FPFV or EZLN and whose support became particularly influential during the last phases of the conflict. ${ }^{10}$

This constitutes one of the most significant contrasts between the Mexican and the Bolivian case studies. The Bolivian shows a similar division between 'radicals' and 'moderates', but the separation is only relevant throughout the first stages of mobilisation. Coordinadora supporters were first split between those who wanted mere amendments to the contract with AdT and those who wanted its full cancellation. This distribution changed after technical advisors to Coordinadora found and publicised more technical and legal faults in the concession contract and in the respective legal reforms. At the same time, government representatives committed significant political errors; they dismissed Coordinadora as an invalid channel of representation, ordered the detention of movement spokespeople, and backed the repression of protests and marches in early 2000.

While the accumulation of demands and the attraction of radical powerful allies eventually eclipsed the interests of moderate groups that had supported Frente Popular in Mexico, Cochabamba experienced a radicalisation phase that aligned different constituencies, both moderate and radical. The peak of this radicalisation in the Bolivian case became obvious when Coordinadora organised a public consultation which estimated that 96 percent of the population supported the cancellation of the concession contract. This was followed by a week of continuous demonstrations and road blockades that culminated in protesters bypassing the Coordinadora spokespeople, taking over the headquarters of the local water company

10 An example is Ejército Popular Revolucionario (EPR), a guerrilla that endorses a much more confrontational discourse. See Bruhn (1999: 29-30). 
(Servicios Municipales de Agua Potable: SEMAPA), and demanding that AdT should leave the country. Only a few voices expressed discontent immediately after the private concessionaire was expelled from Bolivia.

The second obstacle in Atenco was socio-political contextual. From a comparative perspective, the Mexican party system was still experiencing the last spurts of confidence after the first opposition party president had been elected one year before the project's official announcement, whereas the Bolivian political party system was experiencing a crisis of representation in 2000. Therefore, the discourse publicised by Coordinadora was more likely to echo across broader sectors of the population. The struggle found resonance with groups calling for 'participatory democracy' across broad constituencies that were very dissimilar at the outset. This was not the case in Mexico, where public opinion and key supporters alienated from Frente Popular after radical sectors took over the course of the movement and demanded Atenco to be declared an autonomous municipality. Overall, the political opportunity structure in Mexico was narrower because PAN had just won the presidential elections after more than seventy years of uninterrupted PRI rule, and broad sectors of the Mexican population were optimistic about the political transition.

Thirdly, it is also possible that tensions between different factions of the social movement in Atenco were exacerbated by the organisational traits of Frente Popular, which seems to be more hierarchical and centralised in comparison to Coordinadora in Cochabamba and which seems to have some characteristic ingredients of what Cornelius (1975:139-150) calls 'urban caciquismo'. Supporters of Coordinadora could express openly their opinions as long as they kept participating actively and continuously; the people's inputs and concerns were actually taken into account, based on the idea of the 'plebeian crowd'. In contrast, even though supporters of Frente Popular were welcome to join the movement of resistance, their opportunities to contribute to the movement's discussion were more restricted (Reforma 2209-02). This factor shaped the spaces for participation, created asymmetries between different movement supporters, and contributed to channelling the processes of identity formation and demand-making in a different manner. Thus, the dialogical relation between the hidden processes of identification and the more visible articulation of demands in the case of Atenco was thwarted when it came down to taking certain strategic and tactical decisions such as whether to negotiate with the government, and whether to release control of the municipal offices after the project was cancelled. 
Fourth and finally, Frente Popular never managed to construct a discourse that was nearly as inclusive and elaborated as that of Coordinadora. Whereas Coordinadora's core claims travelled much better across different social groups - i.e. 'water is a condition for the reproduction of life'-, this was not the case of Frente Popular who endorsed more issue-oriented claims such as 'land is not for sale' or less credible demands as 'declaring an autonomous municipality'. In this respect, the differing levels of elaboration and inclusiveness between both discourses are partly explained by the nature of the respective grievances, but they are also partly explained by the differing organisational experience of the movement leaders. Even though people in Atenco had some mobilising experience derived from organising traditional festivities and from articulating their demands against the state, this was not comparable with the experience that the key members and spokespersons of Coordinadora could offer to the movement in Bolivia. Some of those who joined the opposition against AdT were former leaders from mining centres that closed down in the late 1980s and who migrated to Chapare and to the City of Cochabamba. Others were leaders of active unions and yet others were intellectuals who were involved in social movements and guerrillas throughout the 1970s and 1980s. ${ }^{11}$

\section{Conclusions}

This work has used two case studies to illustrate the ways in which framing strategies and discursive practices explain the emergence and development of social movements. Although both case studies present significant sociopolitical differences, they have similar storylines and they comprise examples of a more general phenomenon that affects Latin America: the difficulty to discuss, negotiate, and implement mega-infrastructure projects in the context of social, political, and economic changes that the region has experienced in the last twenty years. In this context, the article constitutes a modest contribution to the understanding of how and why social movements emerge and develop during and after opposition to large infrastructure projects.

By focusing on the study of their respective collective action frames, the article has argued that the most significant difference between Coordinadora in Bolivia and Frente Popular in Mexico was the extent to which contextual and/or organisational conditions hampered or facilitated

11 An example is the current Vice-president, Álvaro García Linera, who used to support the Revolutionary Movement Tupac Katari (MRTK). 
the dialogical relation between discourses publicised in the public sphere and the construction of identities at the micro-sociological level. In the case of Bolivia, the conditions that allowed this dialogical relation were three: the discredit of neoliberal policies accumulated between 1985 and 2000; the low levels of legitimacy enjoyed by a loose governing coalition led by former military dictator Hugo Banzer; and Coordinadora's loose and flexible organisational structure. In the case of Mexico, the conditions that hampered the resonance between constructed discourses and collective identities were mainly four: the unsustainable social movement alliances that emerged throughout the various stages of conflict; the absence of a clearer political opportunity given the first victory of an opposition party in the presidential elections of 2000; the more hierarchical organisation of Frente Popular, and the movement's framing strategies, which became more radical towards the end of the conflict.

\section{Bibliography}

Assies, William (2003), "David versus Goliath in Cochabamba. Water Rights, Neoliberalism, and the Revival of Social Protest in Bolivia", in Latin American Perspectives, vol. 30, no. 130, San Diego, California.

Bayard de Volo, Lorraine (2004), "Mobilizing Mothers for War. Cross-National Framing Strategies in Nicaragua's Contra War", in Gender and Society, vol. 18, no. 6, Newbury Park, California.

Berbrier, Mitch (1998), "Half the Battle: Cultural Resonance, Framing Processes, and Ethnic Affectations in Contemporary White Separatist Rhetoric", in Social Problems, vol. 45, Oakland, California.

Bruhn, Kathleen (1999), "Antonio Gramsci and the Palabra Verdadera: The Political Discourse of Mexico's Guerrilla Forces", in Journal of Interamerican Studies and World Affairs, vol. 41, no. 2, Miami, Florida.

Cornelius, Wayne (1975), Politics and the Migrant Poor in Mexico City, Stanford, California: Stanford University Press.

Crabtree, John (2005), Patterns of Protest. Politics and Social Movements in Bolivia, London: Latin America Bureau.

Crespo, Carlos (2000a), "Los Actores Estatales en la Guerra del Agua", in CERES, no. 3, Cochabamba, Bolivia.

Crespo, Carlos (2000b), "La Guerra del Agua en Cochabamba: Movimientos Sociales y Crisis de Dispositivos de Poder", in Ecología Política, no. 20, Barcelona, España.

Crespo, Carlos and Susan Spronk [eds.] (2007), Después de las Guerras del Agua, La Paz, Bolivia: Plural Editores. 
Convergencia Revista de Ciencias Sociales, núm. 69, 2015, Universidad Autónoma del Estado de México

Davis, Diane and Cristina Rosán (2004), "Social Movements in the Mexico City Airport Controversy: Globalization, Democracy, and the Power of Distance", in Mobilization: An International Quarterly, vol. 9, no. 3, San Diego, California.

Della Porta, Donatella and Mario Diani (1999), Social Movements: An Introduction, Oxford: Blackwell.

Domínguez, Carlos (2007), "Discursos e Identidades en la Guerra del Agua: Explicaciones Alternativas y Perspectivas Futuras”, in Carlos Crespo and Susan Spronk [eds.], Después de las Guerras del Agua, La Paz, Bolivia: Plural Editores.

Domínguez, Carlos (2011), "Megaproyectos, infraestructura y los límites de la democracia delegativa”, in Revista Legislativa de Estudios Sociales y de Opinión Pública, vol. 4, no. 7, Mexico City.

EDOMEX (2003), Cronología de Actividades del Frente de Pueblos en Defensa de la Tierra, Mexico City: Under-Ministry of Ecatepec's Regional Government.

Gamson, William (1991), "Commitment and Agency in Social Movements", in Sociological Forum, vol. 6, no. 1, New York.

Gamson, William (1992), “The Social Psychology of Collective Action”, in Aldon Morris and Carol Mueller, Frontiers in Social Movement Theory, New Haven: Yale University Press.

Gamson, William and David Meyer (1996), "Framing Political Opportunity", in D. McAdam, McCarthy, J. D. et al., Comparative Perspectives on Social Movements: Political Opportunities, Mobilizing Structures and Cultural Framings, Cambridge: Cambridge University Press.

García Linera, Álvaro, Chávez León, Marxa and Patricia Costas Monje (2004), Sociología de los movimientos sociales en Bolivia: Estructuras de movilización, repertorios culturales y acción politica, La Paz, Bolivia: Diakona and Oxfam.

García Linera, Álvaro, Gutiérrez Raquel and Raúl Prada (2000), El retorno de la Bolivia plebeya, La Paz, Bolivia: Muela del Diablo Editores.

García Linera, Álvaro, García Fernando and Luz Quintón (2003), La “Guerra del Agua”. Abril de 2000: La Crisis de la Politica en Bolivia, La Paz: PIEB.

Hammond, John (2004), “The MST and the Media: Competing Images of the Brazilian Landless Farmworkers' Movement”, in Latin American Politics and Society, vol. 46, no. 4, Miami, Florida.

Kurzman, Charles (1996), "Structural Opportunity and Perceived Opportunity in SocialMovement Theory: The Iranian Revolution of 1979”, in American Sociological Review, vol. 61, no. 1, Philadelphia.

McAdam, Doug (1982), Political Process and the Development of Black Insurgency, 19301970, Chicago: University of Chicago Press.

MacAdam, Doug, McCarthy, John and Zald Mayer (1996), Comparative Perspectives on Social Movements: Political Opportunities, Mobilizing Structures and Cultural Framings, Cambridge: Cambridge University Press.

Melucci, Antonio (1989), Nomads of the Present: Social Movements and Individual Needs in Contemporary Society, Philadelphia: Temple University Press. 
Nash, June (2001), Mayan Visions. The Quest for Autonomy in an Age of Globalization, New York, London: Routledge.

Noonan, Rita (1995), Women Against the State: Political Opportunities and Collective Action Frames in Chile's Transition to Democracy, Sociological Forum 10 (1), New York.

Olivera, Oscar and Tom Lewis (2004), Cochabamba! Water War in Bolivia, Cambridge, Mass.: South End Press.

Perreault, Tom (2006), From the "Guerra del Agua" to the "Guerra del Gas": Resource Governance, Neoliberalism, and Popular Protest in Bolivia, Antipode, vol. 38, no. 1, New Jersey.

Salinas, Javier and René Ramón Alvarado (2002), "Brutal represión policial a una marcha campesina provoca revuelta en varias poblaciones mexicanas. Reprimen marcha en Atenco", in La Jornada, Mexico.

Schattschneider, Elmer Eric (1960), The Semisovereign People: a Realist's View of Democracy in America, New York: Rinehart and Winston.

Snow, David and Robert Benford (1992), "Master Frames and Cycles of Protest”, in Aldon Morris and Carol Mueller, Frontiers in Social Movement Theory, New Haven: Yale University Press.

Snow, David and Robert Benford (2000), "Framing Processes and Social Movements: An Overview and Assessment", in Annual Review of Sociology, vol. 26, Palo Alto, California.

Snow, David, Rochford, Burke, Steven Worden and Robert Benford (1986), "Frame Alignment Processes, Micromobilization and Movement Participation", in American Sociological Review, vol. 51, no. 4, Philadelphia.

Steinberg, Marc (1999), “The Talk and Back Talk of Collective Action: A Dialogic Analysis of Repertoires of Discourse among Nineteenth-Century English Cotton Spinners", in American Journal of Sociology, vol. 105, no. 3, Chicago, Illinois.

Tarrow, Sidney (1994), Power in Movement: Social Movements and Contentious Politics, Cambridge and New York: Cambridge University Press.

Tilly, Charles (2003), The Politics of Collective Violence, Cambridge: Cambridge University. Van Cott, Donna Lee (2003), "From Exclusion to Inclusion: Bolivia's 2002 Elections”, in Journal of Latin American Studies, vol. 35, no. 4, London, UK.

Zavaleta, René (1983), Las Masas en Noviembre, Mexico City: Siglo XXI.

\section{Electronic resources}

Ortega, Berenice (2005), “San Salvador Atenco: La Formación de una Identidad de Clase en la Resistencia”, CLACSO, Buenos Aires. Available at: http://clacso.org.ar/biblioteca (July $1^{\text {st }} 2007$ ).

Reforma (2003), “Queda Atenco en suspenso”. Available at: http://busquedas.gruporeforma. com/ (June $4^{\text {th }} 2007$ ). 
Reforma (2001), “Divide a ejidatarios defensa de tierras". Available at: http://busquedas.

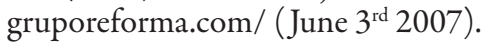

Reforma (2002), “Autónomos y Divididos”. Available at: http://busquedas.gruporeforma. com/ (June $\left.4^{\text {th }} 2007\right)$.

\section{Selected Interviews in Bolivia}

Crespo Flores, Carlos, Academic and technical advisor to Coordinadora, Interview in Cochabamba Bolivia, $11^{\text {th }}$ August 2005.

López, Claudia, Activist during the Water War, Interview in Cochabamba, Bolivia, $13^{\text {th }}$ August 2005.

Mamani, Carlos, Aymara Historian, Interview in La Paz Bolivia, September 2005.

Olivera, Marcela, Interview in Cochabamba, Bolivia, $13^{\text {th }}$ August 2005.

Olivera, Oscar, Coordinadora's main spokesman, Interview in Cochabamba, Bolivia, $12^{\text {th }}$ August 2005.

Quintana, José Ramón, Political Consultant, Interview in La Paz Bolivia, August 2005.

\section{Selected Interviews in Mexico}

Del Valle, Ignacio, Spokesman and leader of Frente Popular, Interview in Atenco, Mexico City, August 2003.

Espinoza, Adán, Spokesman and leader of Frente Popular. Interview in Atenco, Mexico City, August 2003.

Kuri-Pérez, Francisco, Presidential Representative to Negotiate the Conflict in Atenco, Interview in Mexico City, December 2005. 
J. Carlos Domínguez. DPhil in Development Studies, University of Oxford, United Kingdom. Full-time researcher at "Dr. José María Luis Mora" Institute in Mexico. His current research interests include: comparative politics; public policy and social movements in Latin America; security and development. Recent publications: "Participación, democracia y el doble reto de la infraestructura en México', in Miguel Armando López Leyva et al., Tensiones y Desafios de la Democracia (2013); "Desplazamiento por Proyectos de Desarrollo: Retos para Enrique Peña Nieto", in Metapolitica, no. 82, julioseptiembre (2013); "When the Environmental Displaces the Social: The Project for a New Airport in Mexico City during the Fox Administration”, in Latin American Policy: A Journal of Politics and Governance in a Changing Region, vol. 3, no. 2 (2012).

Reception: March 21 $1^{\text {st }}, 2014$.

Approval: May 6 $6^{\text {th }}, 2015$. 
